Swarthmore College

Works

\title{
"Black Panther:" Some Thoughts On Anti-Colonialism, Feminism, Xhosa, And Black Pixels In The Film (With An Aside On Ava DuVernay's "A Wrinkle In Time")
}

Peter Schmidt

Swarthmore College, pschmid1@swarthmore.edu

Follow this and additional works at: https://works.swarthmore.edu/fac-english-lit

Part of the English Language and Literature Commons

Let us know how access to these works benefits you

\section{Recommended Citation}

Peter Schmidt. (2019). "'Black Panther:" Some Thoughts On Anti-Colonialism, Feminism, Xhosa, And Black Pixels In The Film (With An Aside On Ava DuVernay's "A Wrinkle In Time")". English Literature Faculty Works. DOI: 10.24968/2476-2458.engl.346

https://works.swarthmore.edu/fac-english-lit/346

This work is brought to you for free by Swarthmore College Libraries' Works. It has been accepted for inclusion in English Literature Faculty Works by an authorized administrator of Works. For more information, please contact myworks@swarthmore.edu. 


\title{
Black Panther: Some Thoughts on Anti-Colonialism, Feminism, Xhosa, and Black Pixels in the Film (with an aside on Ava DuVernay's A Wrinkle in Time)
}

\author{
Peter Schmidt \\ Swarthmore College
}

Amidst the acclaim Ryan Coogler's Black Panther has rightly received, there are some vociferous debates going on about the film's portrait of Erik Killmonger (Michael B. Jordan). See the Boston Review website, for example, with Christopher Lebron's essay asking why the character who most strongly articulates an anti-white supremacy and anticolonialist vision is cast as the primary villain. ${ }^{1}$ Good question. But in making his case, Lebron gets some things seriously wrong about both Killmonger and T'Challa.

What the movie stresses (via a newly created backstory for Killmonger written by Coogler and Joe Robert Cole) is that Erik Killmonger's in part a creation of the U.S. endless war, "anti-terrorist" machine. He gets his nickname and new identity in Afghanistan, and it is there that he learns to weaponize his rage. Killmonger's global vision is focused primarily on military power \& revenge (thus his irrational burning of Wakanda's blue healing plant garden). In the process, Killmonger becomes the thing he hates. Perhaps that's why his first name is spelled with a Germanic "k": Erik. Names in comics and other allegorical forms of story telling are almost always heavily symbolic, telling us how to interpret the characters. Consumed by anger and a vision of weaponry and power as the solution to his anger and hurt, without any irony he channels the British Empire's slogan of wanting to create an empire upon which "the sun never sets" as his boast, his dream. Killmonger's allegedly pan-African vision has little in common with (say) W. E. B. DuBois's, or with the original Black Panther Party's views about racism and colonialism in the 1960s - both of which centered on a critique of colonialism. But understanding and feeling Killmonger's rage is crucial for understanding and feeling the movie. As Aviva Chomsky has pointed out, "Not only does the film take on the political

\footnotetext{
${ }^{1}$ https://bostonreview.net/race/christopher-lebron-black-panther
} 
economy of colonialism in Africa, it also raises the question of how colonialism shaped the African diaspora."2

Despite having vibrant heroines, the movie is primarily patriarchal, with the implication that so are all African nations or tribes. The drama at the heart of the film is this: which male will be King? But shadowing that drama is a backstory of Black patriarchal betrayal: Killmonger's abandonment or rejection as a child. Hurt and angry, Killmonger turns to a different authority-figure, the American military, and then eventually kills that "father" — while keeping its weapons — and seeks to conquer Wakanda. In a profoundly moving but also disturbing way, the African diaspora's sense of homelessness, abandonment, lost ancestral roots, and betrayal, is embodied in Killmonger. And he seeks revenge against Africa, not just against white colonialism. Killmonger is at least as angry at Wakandan leadership as he is at white supremacy. T'Challa has to fight Killmonger because in confronting him he is combatting a particular, partly Americanformed vision of Black power that says victory can only be achieved via a Black empire of world domination and subjugation that outdoes all previous colonial empires. Killmonger's probably the best "villain" in the Marvel universe because he's not inherently evil, but was made evil — a tragic hero fated with a tragic flaw, not just a villain with reams of scars. And we should remember that some of the best heroes in the world of comics have as their motivation avenging the murder of a parent.

The movie's script thus points to a tragic irony: identifying with the slaves and victims of history (most clearly present in his moving death speech), Killmonger is even more profoundly identifying with the enslavers, their murderous power and their drive to maximize profits. Don't forget that most of those scar marks on his buff body signify kills he made working for the U.S. military in Afghanistan. (Others represent kills done in the U.S., for reasons I wish the script had explored further: who were those victims?)

2 Aviva Chomsky, "Why Black Panther Is Revolutionary, Even Though It Isn't.” Common Dreams website, 28 Feburary 2018. Chomsky also argues that "Killmonger's vision for black liberation has been distorted, not by his advocacy of violence to overthrow white supremacy, but by the non-Wakandan, American, white supremacist world that formed him. https://www.commondreams.org/views/2018/02/28/why-black-panther-revolutionary-even-though-it-isnt 
Let's consider a little more carefully the root cause of Killmonger's agony and how it is represented in Black Panther.

It all begins with his father. N'Jobu (Sterling K. Brown), is killed by T'Challa's father, T'Chaka, in revenge for helping Ulysses Klaue obtain Vibranium. Why N'Jobu would so betray Wakanda is unexplained, or if it was I missed it. N'Jobu hardly needed whatever money Klaue offered him. A different, intriguing possibility presents itself: perhaps N'Jobu's foolhardy greed is an allegorical repetition of the sin of those African kings who for a quick profit sold a different kind of priceless African resource-Africans themselves - to European slavers. In late modernity (however you date the "present" time in which Black Panther is set), the dreadful history of slavery repeats itself with new variations. For his sin N'Jobu was killed, and as a further punishment T'Chaka disowned and abandoned N'Jobu's son, T'Challa's young cousin, and he grows up to become Killmonger. ${ }^{3}$

The scene in Oakland, California, where Killmonger is disowned by his uncle is powerfully recreated in the movie through a film montage juxtaposing and repeating scenes from two stages of Killmonger's life, as a boy and then as a man who returns to the scene of the crime, so to speak. In both moments of time he cries. The anger that arises can never be healed by weaponry, nor by however many kills he obtains. ${ }^{4}$ When Killmonger turns his gaze to Wakanda, he wants to do a makeover on it, turning it from isolationism, a kind of Switzerland in Africa, into the greatest imperial Empire the world has ever seen. His first gift to Wakanda's leadership: the body of Ulysses Klaue. It's as if he has put in his body bag a corpse symbolizing white colonialism itself, its depredation of African resources, including its people. Yet Killmonger's anger focuses laser-like on Wakanda as well, his certainty that it has betrayed him. His only way of

\footnotetext{
3 Black Panther's indictment of certain African kings for profiting from slavery should NOT be interpreted as saying "Africa was guilty for slavery too." Whites profited far more greatly from the slave trade, slave labor, and slave breeding, and bear by far the biggest share of guilt. But unfortunately when it comes to Black slavery there is more than enough guilt to go around. One driving force of Black Panther could arguably be said to be these questions: what reparations are due for slavery? How should they be paid? 4 An aside: there's an intriguing essay to be done on the role of men's tears in the movie, most notably T'Challa's and Killmonger's. Do any of the women ever cry? How should we understand T'Challa's tears?
} 
conceiving how Black Power can be recognized in this evil world is to conceive of it as a colonial empire with a secret ingredient, one that will be even more dominant and violent than previous ones, whether British, Dutch, German, Belgian, or French — or American. For Killmonger, racist power concedes nothing without a fight; he aims to change the balance of power by arming Black people all over the world with weapons powered by Vibranium. This too has deep echoes in Oakland history and in the history of Black Panther militancy. As one article in the LA Times recalled, "The Panthers were initially a kind of neighborhood watch for Bay Area blacks; when they saw a white cop stop a black motorist, they would approach with guns drawn, demanding that the cop respect the black man's civil rights."

Partly under pressure from Killmonger, and with increasing knowledge of Black desperation world-wide, King T'Challa (Chadwick Boseman) rejects his original isolationist vision of how Wakanda should define its destiny. Yet T'Challa's alternative vision of Black Power and Black world leadership takes awhile to develop. What causes this gradual revolution in his world view is a crucial part of Black Panther's plot-line, yet it's a fascinating story too poorly noticed, much less explored, in the many reviews and comments the movie has received. Before defining what T'Challa's mature vision of Black leadership is, let's look at what causes his change. Arguably Nakia (Lupita Nyong'o) and Erik Killmonger play the most important roles here. Early in the film we encounter Nakia's heroic anti-terrorist work against a group remarkably like Nigeria's Boko Haram: she rescues kidnaped girls from a fate of African slavery and rape. Later, it's primarily Nakia who pushes the King to use Wakanda's powers to intervene against injustice worldwide, whether in African nations or (very pointedly, near the film's climax) the homegrown American structural racism that destroys opportunities for a new generation of kids in Oakland.

Thus Oakland, one of the U.S. cities most strongly associated with Black Panther social activism in the 1960s and early 1970s, is the pivot on which T'Challa's vision of

5 Eric Burrough, article from May 2, 2015: http://www.latimes.com/opinion/op-ed/la-oe-0503-burroughviolent-revolution-20150503-story.html . 
leadership changes. Killmonger's revelation to King T'Challa about what happened to him in Oakland profoundly shakes T'Challa. Channeling his own inner Killmonger, T'Challa in a dream-nightmare journeys into the world of dead Panther elders and, in one of the most remarkable scenes in the film, confronts the previous King, John Kani's T'Chaka, the one guilty of abandoning the Black boy who became Killmonger. T'Challa forces the Black Panther lineage to confront their failures as moral leaders, despite Wakanda's miraculous material prosperity. Hence the Oakland Black Panther heritage that the film most honors is its drive for social justice and equal opportunity, including breakfasts and a better education for the children of Oakland. Not the notorious photographs - infinitely reproduced and then condemned by the white press — of Black Panthers brandishing weapons and speaking of revenge, not just self-defense. At the film's end, Nakia's and T'Challa's new community-based program for aiding Oakland youth models itself on original Panther initiatives, though now of course they have Wakandan Superpower funding backing up their plans for social transformation. The final Oakland scene ends with a poignant juxtaposition of colonized minds and hope: seeing T'Challa's cool ride chilling on the basketball court, most of the boys want to figure out how to steal and dismantle it to sell for quick cash. But one curious boy approaches the cool dude in his black suit and asks, "where are you from?" T'Challa is about to reverse what happened to Killmonger.

Some of King T'Challa's clashing concepts of kingship in the movie can rightly be called Shakespearean, but a real-life African leader inspired the movie's vision of how T'Challa may successfully balance power and ethics, tradition and innovation, and global consciousness coupled with a rejection of a demonic previous form of globalism, the colonial/imperial model for world power. You can probably guess who that statesman is: Nelson Mandela. Not for nothing does the movie begin with dialogue in (click) Xhosa, one of South Africa's official languages. Wakanda's language in the movie is Xhosa, though the major characters' facility with many languages, including English and Korean, is also emphasized. ${ }^{6}$ To complete Mandela's ghostly fatherly presence in the

\footnotetext{
6 How much of the dialogue we hear in English is actually spoken in Xhosa, or the imaginary Wakandan tongue for which Xhosa is a stand-in? It's a fascinating question I've no idea how to answer.
} 
movie, T'Challa's dress, manner, and the moral vision of his speech addressing the U.N. near the movie's conclusion invoke no world leader more strongly than Mandela — both in its pan-Africanism and in its vision of the centrality Africa in all its diversity must play in making a truly global community. Mandela is Killmonger's opposite. ${ }^{7}$

Let's now consider briefly the movie's Black feminism, especially its exemplars Nakia the healer (Lupita Nyong'o), Okoye the warrior/head of the King's guard (Danai Gurira), Shuri the wiz (Letitia Wright), and Ramonda the queen (Angela Bassett). Despite the fact that Angela Bassett's part was seriously under-written and under-imagined, Black Panther has rightly been celebrated for its powerful, positive role models for women's heroism and intelligence. The movie stresses the central role women must play in creating and running Wakanda. Each of the three heroine's characters is well developed, their courage and moral leadership honored, though it's interesting how little backstory we get on any of them (in striking contrast to the two main male leads). As I've argued, King T'Challa's view of leadership could not evolve as it did without guidance from the four primary women characters, particularly Nakia. But to assert that is also to recognize that the women also serve a society that is primarily patriarchal, based as it is on male succession rituals and trial by physical combat.

Where are the daughters in Black Panther? Where are their stories? Most of the young girls we see in the film are wearing khimars and long robes, cowering and silent when rescued by Nakia. We get no story about how Nakia, Okoye, or Shuri became who they are, including what role parental figures female and male played in their nurturing. Interestingly, about a month after the 2018 release of Black Panther came the debut of another Black-helmed film, Ava DuVernay's A Wrinkle in Time - a film that, like its source-text by Madeline L'Engle, does place at the heart of its story a girl's development of her Superpower aided by three mother-figures as well as others, including of course

\footnotetext{
7 For more on Killmonger's possible future in the Black Panther film franchise, see https://screenrant.com/black-panther-2-killmonger-death-return/
} 
her own version of an absent father. Although the plot of A Wrinkle in Time is driven by Meg's desire to rescue her father - a version of the CIA plays a villainous role in both films, by the way ${ }^{8}$ - he and other males in the novel arguably play a somewhat lesser role in her discovery of her Superpower than her mother and, particularly, the three witches and Aunt Beast. Though both films had Black directors, a majority Black crew, generous budgets, major Hollywood studio backing, and both work by revising and re-imagining source material originally created by whites, Black Panther was instantly acclaimed as a world-historical, transformative cultural turning point for Africa and the African diaspora. A Wrinkle in Time, when it's been discussed at all, in contrast has been treated just as primarily a film for young girls or, perhaps, also a film about coming to terms with multi-racial identity. The disparity between these two different critical frames for imagining the cultural "importance" of Black Panther vs. A Wrinkle in Time is profoundly sexist. Yet DuVernay's and L'Engle's story goes where Black Panther does not tread.

Here are some other seriously cool Black Panther topics worth exploring further, though I'll just sketch some possibilities here. It's obviously not a complete list:

- The movie's critique of contemporary militarism and its racist colonial roots. In exploring this, the focus should not be just on Ulysses Klaue [Claw], whose epic monomania is played with gusto by Andy Serkis. Martin Freeman's CIA operative Everett K. Ross is the key to how the movie implicates the U.S., not just colonialism in general, in Black Panther's attack on racism. Particularly intriguing here is its critique of the "uplift" narratives by which imperialism justified itself — colonialism was supposedly all about "developing" rather than exploiting conquered territories, bringing modernity and human rights to backward nations. As Ross's dialogue reveals, when after the 1890s the U.S.

8 In L'Engle's novel, the heart of evil is mockingly called the Central Central Intelligence Agency, and it is interested in dominating the Universe, not just the Earth. Meg's father is an atomic scientist, so the novel - perhaps inspired by President Eisenhower's farewell speech warning against the military-industrial complex destroying American democracy - is not unlike Black Panther or other sf in its worries about how science may be coopted by racism, a drive for military empire, and a death-wish. 
decided to stake its own claims on the Caribbean and the South Pacific, it adapted British, Belgian, Dutch, French, and German narratives about how they were civilizing the Caribbean, Africa, India, and Asia. Linking both the U.S.'s early imperial adventures with its post-World War II hubris claiming to defend human rights world-wide against the threat of Communism, Black Panther's Ross gets comic comeuppance as he is schooled by Wakanda's Shuri in what modern technology and enlightened social and economic development really looks like. This CIA operative has to learn to humble himself and open his mind to completely new ideas that are the antithesis of white supremacy and its somewhat milder cousin, white entitlement. Thus one of the movie's many projects (as was true for the Black Panther comics) is the re-education of whiteness. Ross has to learn to respect Black leadership and to take a bit part in the main narrative. Given the trailer about Black Panther 2 that was shown at the end of the showing I attended, it looks like re-educating whiteness is planned to be an important plotline in the Black Panther sequel as well. Any further exploration of white characters, however, should be placed within the franchise's historical reinterpretation of colonialism, racism, and their long-range effects. Klaue and Ross, for instance, perhaps too neatly represent the two faces of imperialismbrute violence in the name of extracting and controlling resources, vs. a cover story that stressed the West's benevolence and cultural superiority, not savagery. Whether future movies go beyond this somewhat simple dichotomy will be interesting to see.

- Black Panther's vision of Wakanda as a society that can be both profoundly urban and also full of thriving small villages and farms has precedents in African history. Check out the history of Timbuktu, for instance, though it wasn't protected by mountains. Can we get more on the political economy of Wakanda, please, in the sequel? The urban market and bazaar scenes in Black Panther were fascinating, but too brief.

- Panther's ethical view of how advanced technology must be united with ancient healing and agricultural arts. I hope the gardens and plants that Killmonger burned are restored in $B P 2$ and play a new role in the plot. As for the role the 
magic plants played in $B P$ 1, note how they're crucial for King T'Challa's journey into the world of the dead, where he must confront the past King with his crime (abandoning his nephew).

- Here's a different hypothesis about high tech that's worth debating or disproving: the movie's vision of technology, especially virtual reality, is coded as both "universal" and "Black." That is, the medical tech Shuri uses to fix Ross' spine will be one of the devices Wakanda will (presumably) share with the world. It's Black-invented but not Black-owned (though presumably once it goes global they'd better secure patent rights!). But there are lots of moments in the film where the glam inventions are even more strongly coded as African (or African/African diasporic?). Unlike the miraculous medical equipment, this tech is replete with African cultural and historical markers; it's not just coded as "pure" science. The most interesting example of this for me was the ways in which virtual or holographic images emerged from and, on Shuri's command, dissolved back into swirling black pixels —as if the "ground" for all virtual reality in the film was, literally, Black. (Black codes?) What should we make of this? Or is the basic distinction I've just sketched a false one? To be clear, in making this hypothesis, I'm NOT claiming that the film makes an absolute or simple distinction between universal and Black technology. Rather, I'm trying to suggest that in fascinating ways Black Panther complicates or makes intersectional these two possible categories for understanding the film's vision of Afrofuturistic technology and its worldwide relevance.

Two quick concluding points. Most of Black Panther is profoundly, dazzlingly Utopian, and skepticism and questions about this are definitely valid. But the film is profoundly in the multi-disciplinary tradition of Afrofuturism - another research topic well worth exploring. In our era soaked in the bile of dysfunction and pessimism we could perhaps use a little of Afrofuturism's critical Utopianism. After all, it's one of the reasons why 
this movie (and the comics, and sf and fantasy) so strongly connects with a global audience.

Second, Ryan Coogler's direction was supremely intelligent. It was fast-paced and intentionally disorienting during the chase and fight scenes, using all the resources of filmic tradition, including dropping props to Hong Kong film-master John Woo for the Korean fight scenes. But in its intimate moments, Coogler dared to take a slow pace and use expressive close-ups allowing crucial stories and emotions to emerge. (Sort of like a close-up frame in the comics, but with motion!) But along with the adept cinematography, we must also celebrate the film's script. The movie smartly reinterprets and updates for 2018 the Panther superhero story, moving well beyond how it was imagined by Stan Lee and Jack Kirby in 1960s/70s and Billy Graham in the 1970s/80s. 9 Let's give props to the skills of Ryan Coogler and his co-writer, Joe Robert Cole; the script is as important as the images for the movie's success.

As King T'Challa says when Wakanda flys into view near the beginning of the movie, "This never gets old."
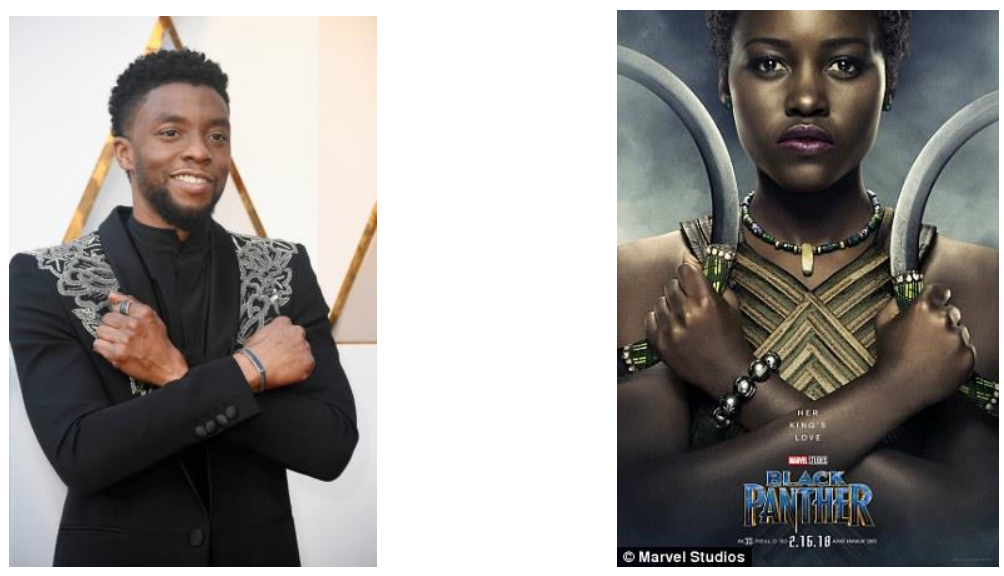

\footnotetext{
9 How Black Panther ignores, adapts, and/or revises characterizations and plotlines from its Marvel sources is a topic that will be fun and invaluable to research. Graham was the only Black artist working for Marvel in the 1970s. Regarding how he reconceived and revised Lee's and Kirby's conception of Black Panther, one place to start is Sean Howe's "Black Panther, Luke Cage, and the First Black Artist to Draw Both": https://www.nytimes.com/2018/03/07/movies/black-panther-luke-cage-artist-billy-graham.html
} 